Check for updates

1 Wolverhampton University, Wolverhampton, UK

2 Hamburg, Germany

3 Unit of Public Health, Healthcare Sciences Institute, Universidade Católica, Portugal

Correspondence to: I Middleton john.middleton@aspher.org Cite this as: BMJ 2020;370:m2716 http://dx.doi.org/10.1136/bmj.m2716 Published: 09 July 2020

\title{
Meat plants-a new front line in the covid-19 pandemic
}

These businesses failed in their duty to workers and the wider public health

John Middleton, ${ }^{1}$ Ralf Reintjes, ${ }^{2}$ Henrique Lopes ${ }^{3}$

Slaughterhouses and meat packing plants have been a major risk for covid-19 infection throughout the pandemic. ${ }^{12}$ Now these outbreaks are centre stage. ${ }^{3}$ They affect whole communities, have far reaching implications, and require intensive public health interventions.

In Germany, public health authorities have been grappling with a huge covid-19 outbreak in Gütersloh, North Rhine-Westphalia. More than 1500 of 7000 workers tested positive for covid-19, and 640000 residents of two affected counties were returned to lockdown conditions. ${ }^{4}$ At one of Portugal's biggest poultry slaughterhouses, at least 129 of the 300 workers contracted covid-19. ${ }^{5}$ The company was closed for a week; additional measures included screening all employees, providing new bathing areas, and strengthening disinfection. Outbreaks in England and Wales have been associated with meat processing in Anglesey, Merthyr Tydfil, Wrexham, and Kirklees. ${ }^{6}$

\section{Contributory factors}

Slaughterhouses and meat processing plants are favourable environments for SARS-CoV-2 transmission. ${ }^{17}$ The virus thrives in lower temperatures and very high or very low relative humidity. Metallic surfaces retain live viruses for longer than other environments. ${ }^{8}{ }^{9}$ A dense production of aerosols combining dust, feathers, and faeces is produced in the plants, and intense water use carries materials extensively over surfaces. Workers must speak loudly or shout over the noise, releasing more droplets and spreading them further. ${ }^{10}$ Workplaces are crowded, and social distancing is difficult.

Other environmental issues that should be explored urgently include the possibility of airborne spread ${ }^{11}$ and the role of air filtration systems-already implicated in the outbreak in Gütersloh. ${ }^{12}$

Sociodemographic and workforce factors implicated in these outbreaks include a youthful workforce more likely to have asymptomatic infections; insecure poorly paid employment that discourages workers from disclosing symptoms for fear of penalty; long hours and coercive contracts; a reliance on migrant workers housed in inadequate overcrowded accommodation and transported on overcrowded buses; and limited or non-existent hygiene measures. ${ }^{17}$

\section{Prevention}

Companies across the meat processing sector should conduct urgent risk assessments and implement a hierarchy of measures to prevent further outbreaks. ${ }^{17}$ These include staggering start, finish, and break times; reducing crowding by adding outdoor breakrooms; and installing barriers between workers, especially on production lines. All workers should be screened for symptoms, including fever, on arrival at work ${ }^{1}$ and isolated quickly if required.

They should also consider operational measures such as reducing the processing rate for animals and carcasses, mandating face coverings, embedding good practice in donning and doffing protective equipment, installing touch-free time clocks, and introducing enhanced cleaning and disinfection regimens. ${ }^{17}$ Health education materials for staff must be culturally appropriate and available in all languages relevant to the local workforce. Face coverings should be compulsory on all forms of mass transport. Finally, employers should encourage workers not to attend if ill, declare their symptoms, and self-isolate. Adequate sick pay is essential during all work absence. ${ }^{137}$

\section{Control}

Early recognition of outbreaks requires strong local surveillance systems. Local health authorities need to work alongside businesses, occupational health services, and health and safety inspection services where these exist. ${ }^{3}$ They should have outbreak plans ready for rapid implementation, including efficient systems for testing, contact tracing, and isolation. ${ }^{13}$ All businesses must recognise their responsibility to public health-in addition to the usual corporate self-interest-and cooperate fully with the authorities when closures are required..$^{14}$

In Germany, outbreaks in meat plants have led to local lockdowns. The reproduction number, or average number of secondary infections produced by one infected person has temporarily risen to $2.88 .{ }^{15}$ In most English regions $\mathrm{R}$ is already around 1-1.1, ${ }^{16}$ and the imperative to consider local lockdowns is now recognised after a spike of cases in Leicester. ${ }^{17}$ The pandemic shows up longstanding inequalities in health, with migrant and other ethnic minority workers again in the frontline facing a high risk of infection. ${ }^{18}$ The Leicester outbreak, for example, has exposed the "open secret" of overcrowded working conditions and ultra low wages endured by some groups. ${ }^{17}$ Rapid and permanent improvements in working conditions and wages are needed, along with sound occupational health services for all ${ }^{19}$ and universal healthcare that includes migrant workers, to encourage help seeking when sick.

While the pandemic continues, meat processing plants will remain potential trigger points for a second wave. In Gütersloh, for example, infections 
are increasing among citizens unconnected with the meat plant or its staff.

The meat industry is highly profitable globally and a major driver of both antimicrobial resistance ${ }^{20}$ and climate breakdown. ${ }^{21}$ People may come to reflect on how they get their meat, what they are prepared to pay for it, and what conditions they expect the animals and the workers to endure so they can have it.

Competing interests: We have read and understood BMJ policy on declaration of interests and declare the following interests: JM is president of the Association of Schools of Public Health in the European Region.

Provenance and peer review: Commissioned; not externally peer reviewed.

1 Dyal JW, Grant MP, Broadwater K, etal. Covid-19 among workers in meat and poultry processing facilities-19 states, April 2020. MMWR Morb Mortal Wkly Rep 2020;69:557-61. doi: 10.15585/mmwr.mm6918e3 pmid: 32379731

2 Van Der See B, Levitt T, McSweeney E. Chaotic and crazy: meat plants around the world struggle with virus outbreaks. Guardian 2020 May 11. https://www.theguardian.com/environment/2020/may/11/chaotic-and-crazy-meat-plants-around-the-world-struggle-with-virus-outbreaks

3 Reuben A. Coronavirus: Why have there been so many outbreaks in meat processing plants? BBC News 2020 Jun 23. https://www.bbc.co.uk/news/53137613

4 Robert Koch-Institut. Täglicher Lagebericht des RKI zur Coronavirus-Krankheit-2019 (COVID-19), 28 Jun 2020. https://www.rki.de/DE/Content/InfAZ/N/Neuartiges_Coronavirus/Situationsberichte/2020-06-28-de.pdf?__blob=publicationFile

5 Agostino S. Número de casos de Covid já chega aos 26 na Sonae e aos 129 na Avipronto. Valor Local2020 May 17. https://www.jornalvalorlocal.com/nuacutemero-de-casos-de-covid-jaacutechega-aos-26-na-sonae-e-aos-129-na-avipronto.html

6 Halliday J. Over 450 cases of COVID-19 reported at food factories in England and Wales. Guardian 2020 Jun 25. https://www.theguardian.com/uk-news/2020/jun/25/over-450-covid-19-casesreported-at-food-factories-in-england-and-wales

7 Durand-Moreau Q, Adisesh A, MacKenzie G, et al. What explains the high rate of transmission of SARS-CoV-2 in meat and poultry facilities? Oxford Centre for Evidence Based Medicine, 4 Jun 2020. https://www.cebm.net/covid-19/what-explains-the-high-rate-of-sars-cov-2-transmissionin-meat-and-poultry-facilities-2/

8 van Doremalen N, Bushmaker T, Morris DH, etal. Aerosol and surface stability of SARS-CoV-2 as compared with SARS-CoV-1. N Engl J Med 2020;382:1564-7. doi: 10.1056/NEJMc2004973 pmid: 32182409

9 Yilmaz N, Eren E, Kalayci Z, et al. Relationship between ultraviolet, hot and humidity with covid-19 outbreak. [Presentation.] Apr 2020.https://www.researchgate.net/publication/340352717

10 Anfinrud P, Stadnytskyi V, Bax CE, Bax A. Visualizing speech-generated oral fluid droplets with laser light scattering. N Engl J Med 2020;. doi: 10.1056/NEJMc2007800. pmid: 32294341

11 Zhang R, Li Y, Zhang AL, Wang Y, Molina MJ. Identifying airborne transmission as the dominant route for the spread of COVID-19. Proc Natl Acad Sci U S A 2020;117:14857-63. doi: 10.1073/pnas.2009637117 pmid: 32527856

12 Exner M. Coronavirus: "circulating air" may have spread covid-19 to 1500 German meat plant staff. Sky News, 24 Jun 2020. https://news.sky.com/story/coronavirus-circulating-air-may-havespread-covid-19-to-1-500-german-meat-plant-staff-12014156

13 Reintjes R. Lessons in contact tracing from Germany. BMJ 2020;369:m2522. doi: 10.1136/bmj.m2522 pmid: 32586833

14 UNITE. Employers have "duty" to safeguard staff and public as more meat factory coronavirus outbreaks suspected. 19 Jun 2020. https://unitetheunion.org/newsevents/news/2020/june/employers-have-duty-to-safeguard-staff-and-public-as-more-meatfactory-coronavirus-outbreaks-suspected/

15 Robert Koch-Institut. Täglicher Lagebericht des RKI zur Coronavirus-Krankheit-2019 (COVID-19), 21 Jun 2020. https://www.rki.de/DE/Content/InfAZ/N/Neuartiges_Coronavirus/Situationsberichte/2020-06-21-de.pdf?_blob=publicationFile

16 ZOE National Study. New daily covid-19 cases in the UK have stopped falling this week, 25 Jun 2020. https://covid.joinzoe.com/post/covid-incidence-stable

17 O'Connor S. Leicester's dark factories show up a diseased system. Financial Times 2020 Jul 3. https://www.ft.com/content/0b26ee5d-4f4f-4d57-a700-ef49038de18c

18 Society of Occupational Medicine. Occupational health: the global value and evidence. 2018. www.som.org.uk/sites/som.org.uk/files/Occupational_Health_the_Global_Value_and_Evidence_April_2018.pdf

19 Public Health England. Beyond the data: understanding the impact of COVID on BAME groups. 2020. https://assets.publishing.service.gov.uk/government/uploads/system/uploads/attachment_data/file/892376/COVID_stakeholder_engagement_synthesis_beyond_the_data.pdf

20 O'Neill J. Tackling drug resistant infections globally: final report and recommendations. The review on antimicrobial resistance. HM Government, Wellcome Trust, 2016.

21 Aleksandrowicz L, Green R, Joy EJM, Smith P, Haines A. The impacts of dietary change on greenhouse gas emissions, land use, water use, and health: a systematic review. PLOS One 2016;11:. doi: 10.1371/journal.pone.0165797 pmid: 27812156
This article is made freely available for use in accordance with BMJ's website terms and conditions for the duration of the covid-19 pandemic or until otherwise determined by BMJ. You may use, download and print the article for any lawful, non-commercial purpose (including text and data mining) provided that all copyright notices and trade marks are retained. 